\title{
Aetiology of severe visual impairment and blindness in microphthalmos
}

\author{
Mark J Elder
}

\begin{abstract}
Microphthalmos occupies a spectrum from a normal, but small globe, to a globe with multiple anterior and posterior segment abnormalities. This study examines 54 eyes of 27 patients who had bilateral microphthalmos and severe visual impairment or blindness. Congenital cataract was the commonest cause of severe visual impairment (44\%), followed by presumed retinal or optic nerve displasia $(30 \%)$ and chorioretinal coloboma $(22 \%)$. Lensectomy was followed by phthisis bulbi in $3 / 23$ cases and retinal detachment in $2 / 23$ cases. There were no cases of angle closure glaucoma. The three clinical conditions associated with a poor prognosis were cataract, chorioretinal coloboma, and a markedly reduced corneal diameter. A corneal diameter of $6 \mathrm{~mm}$ or less was associated with a visual acuity of no perception of light in $81 \%(21 / 26)$ compared with $4 \%(1 / 28)$ of those with larger corneas.

(Brf Ophthalmol 1994; 78: 332-334)
\end{abstract}

Microphthalmos is an ocular defect where the overall size of the globe is smaller than normal. The condition has been classified into simple or complex microphthalmos. ${ }^{1-3}$ Simple microphthalmos is where the globe is small, but otherwise normal. This is also called pure microphthalmos or nanophthalmos. Complex, or complicated, microphthalmos is where the globe has other associated abnormalities. Both types may be associated with an orbital cyst or other systemic abnormalities or syndromes. In general, microphthalmos is congenital but occasionally may be acquired because of arrested development.

Microphthalmos can be defined as an eye with an axial length more than 2 SD smaller than the normal for that age group. This equates to an axial length less than $19.2 \mathrm{~mm}$ at age 1 year and less than $20.9 \mathrm{~mm}$ as an adult. ${ }^{1}$ There is a strong linear correlation between the horizontal corneal diameter and the axial length from diameters of $2 \mathrm{~mm}$ to $11 \mathrm{~mm}$. $^{2}$

The ocular abnormalities associated with complex microphthalmos are broadly subdivided into anterior segment dysgenesis, lens abnormalities, chorioretinal coloboma, retinal dysplasia, and persistent hyperplastic primary vitreous (PHPV). ${ }^{1-12}$ Syndromes associated with microphthalmos number more than 100 and all modes of inheritance have been described. ${ }^{13}$ Systemic syndromes include the HallermanStrieff syndrome, ${ }^{14}$ the Meckel-Gruber syndrome, trisomy 13, and the cerebro-oculofacioskeletal (COFS) syndrome. ${ }^{13}$ is

The aim of this study was to determine the main mechanisms causing impaired vision within a group of patients with microphthalmos who were bilaterally legally blind.

\section{Patients and methods}

All six academic blind schools of the West Bank and Gaza strip were visited prospectively, and the children examined. ${ }^{16}$ There were 241 children aged from 5 to 25 years with visual acuities less than $6 / 60$, irrespective of their ocular diagnosis. There were no exclusion criteria.

Each school was visited by the 'Outreach' facility of the St John Ophthalmic Hospital, Jerusalem, which is a well equipped mobile clinic. A complete history was taken and the previous medical records were reviewed. A full examination was conducted, including best corrected visual acuity with Sheridan-Gardner test charts, colour vision assessment, visual field testing by confrontation, slit-lamp biomicroscopy, retinoscopy, cycloplegic refraction, and funduscopy. The corneal diameters were measured as the horizontal meridian from 'white to white' using the adjustable length of the light beam of a standard Topcon slit-lamp. When indicated, children were sent to the base hospital for further investigations such as ultrasound. All microphthalmic patients in this study were examined by the author.

The criterion for inclusion was bilateral microphthalmos with a best corrected visual acuity of less than $6 / 60$ in the better seeing eye. This corresponds to the standard WHO definitions of reduced childhood visual acuity of severe visual impairment $(>6 / 60$ to $3 / 60)$ and blindness ( $>3 / 60$ to no perception of light (NPL)). Statistical analysis used $\chi^{2}$ with a Yates' correction.

\section{Results}

Within the total of 241 patients examined, there were 27 patients with bilateral microphthalmos who had a visual acuity of less than $6 / 60$ and were examined by the author. The mean age was 10.3 years and ranged from 5 to 20 years. A positive family history was present in $37 \%$. The aetiology of visual impairment was divided into three categories; cataract, retinal, and unknown. Each eye was allocated to its respective category by clinically determining the factor which was the major contributor to the visual impairment. These data, along with other ocular abnormalities, are detailed in Tables 1-3. Nystagmus was present in all cases. There were no cases of simple microphthalmos and no patient had facial malformations. Clinically, the vitreous, retina, and optic nerve head were able to be visualised and examined unless stated otherwise.

Within the cataract group, all patients had a diagnosis of cataract before the age of 6 months 
Table 1 Bilateral blindness in microphthalmos primarily due to cataract

\begin{tabular}{|c|c|c|c|c|c|}
\hline $\begin{array}{l}\text { Patient } \\
\text { No }\end{array}$ & $\begin{array}{l}\text { Age } \\
\text { (years) }\end{array}$ & $\begin{array}{l}\begin{array}{l}\text { Corneal } \\
\text { diameter } \\
(\mathrm{mm})\end{array}\end{array}$ & $\begin{array}{l}\text { Visual } \\
\text { acuity }\end{array}$ & $\begin{array}{l}\text { Primary cause } \\
\text { of blindness }\end{array}$ & $\begin{array}{l}\text { Other ocular } \\
\text { abnormalities }\end{array}$ \\
\hline 1 & 5 & $\begin{array}{l}8 \cdot 5 \\
8 \cdot 5\end{array}$ & $\begin{array}{l}3 / 60 \\
3 / 60\end{array}$ & $\begin{array}{l}\text { Congenital cataract } \\
\text { Congenital cataract }\end{array}$ & \\
\hline 2 & 7 & $\begin{array}{l}5.0 \\
5.0\end{array}$ & $\begin{array}{l}\text { NPL } \\
\text { NPL }\end{array}$ & $\begin{array}{l}\text { Congenital cataract } \\
\text { Congenital cataract }\end{array}$ & $\begin{array}{l}\text { No fundal view } \\
\text { No fundal view }\end{array}$ \\
\hline 3 & 7 & $\begin{array}{l}9.0 \\
9.0\end{array}$ & $\begin{array}{l}\text { PL } \\
\text { NPL }\end{array}$ & $\begin{array}{l}\text { Congenital cataract } \\
\text { Congenital cataract }\end{array}$ & $\begin{array}{l}\text { Retinal detachment } \\
\text { Retinal detachment }\end{array}$ \\
\hline 4 & 7 & $\begin{array}{l}8 \cdot 0 \\
8 \cdot 0\end{array}$ & HM & $\begin{array}{l}\text { Congenital cataract } \\
\text { Congenital cataract }\end{array}$ & Thickened capsule \\
\hline 5 & 8 & $\begin{array}{l}8 \cdot 0 \\
8 \cdot 0\end{array}$ & $\begin{array}{l}\mathrm{PL} \\
\mathrm{CF}\end{array}$ & $\begin{array}{l}\text { Congenital cataract } \\
\text { Congenital cataract }\end{array}$ & $\begin{array}{l}\text { Macula coloboma } \\
\text { Macula coloboma }\end{array}$ \\
\hline 6 & 9 & $\begin{array}{l}7 \cdot 0 \\
7 \cdot 0\end{array}$ & $\begin{array}{l}\text { PL } \\
\text { PL }\end{array}$ & $\begin{array}{l}\text { Congenital cataract } \\
\text { Congenital cataract }\end{array}$ & $\begin{array}{l}\text { Aniridia, corneal scar } \\
\text { Aniridia }\end{array}$ \\
\hline 7 & 10 & $\begin{array}{l}4 \cdot 0 \\
4 \cdot 0\end{array}$ & $\begin{array}{l}\text { NPL } \\
\text { NPL }\end{array}$ & $\begin{array}{l}\text { Congenital cataract } \\
\text { Congenital cataract }\end{array}$ & $\begin{array}{l}\text { Phthisis post surgery } \\
\text { Phthisis post surgery }\end{array}$ \\
\hline 8 & 10 & $\begin{array}{l}6.0 \\
6.0\end{array}$ & $\begin{array}{l}\text { CF } \\
\text { NPL }\end{array}$ & $\begin{array}{l}\text { Congenital cataract } \\
\text { Congenital cataract }\end{array}$ & $\begin{array}{l}\text { Optic atrophy } \\
\text { Phthisis post surgery }\end{array}$ \\
\hline 9 & 12 & $\begin{array}{l}7 \cdot 0 \\
8 \cdot 5\end{array}$ & $\begin{array}{l}3 / 60 \\
1 / 60\end{array}$ & $\begin{array}{l}\text { Congenital cataract } \\
\text { Congenital cataract }\end{array}$ & \\
\hline 10 & 13 & $\begin{array}{l}5 \cdot 0 \\
5 \cdot 0\end{array}$ & $\begin{array}{l}\text { NPL } \\
\text { PL }\end{array}$ & Congenital cataract & PHPV \\
\hline 11 & 15 & $\begin{array}{l}8 \cdot 0 \\
8 \cdot 0\end{array}$ & $4 / 60$ & Congenital cataract & Infantile olaucoma \\
\hline 12 & 20 & $\begin{array}{l}8 \cdot 0 \\
8 \cdot 0 \\
8 \cdot 0\end{array}$ & $\begin{array}{l}2 / 60 \\
2 / 60 \\
\mathrm{HM}\end{array}$ & $\begin{array}{l}\text { Congenital cataract } \\
\text { Congenital cataract } \\
\text { Congenital cataract }\end{array}$ & $\begin{array}{l}\text { Intantile glaucoma } \\
\text { Infantile glaucoma } \\
\text { Infantile glaucoma }\end{array}$ \\
\hline
\end{tabular}

$\mathrm{CF}=$ counting fingers; $\mathrm{HM}=$ hand movements; $\mathrm{NPL}=$ no perception of light; $\mathrm{PHPV}=$ persistent hyperplastic primary vitreous; congenital cataract $=$ cataract present before 6 months of age. All patients except No 2 and the right eye of No 11 had previous lensectomies.

Table 2 Bilateral blindness in microphthalmos primarily due to retinal abnormalities

\begin{tabular}{|c|c|c|c|c|c|}
\hline $\begin{array}{l}\text { Patient } \\
\text { No }\end{array}$ & $\begin{array}{l}\text { Age } \\
\text { (years) }\end{array}$ & $\begin{array}{l}\text { Corneal } \\
\text { diameter } \\
(\mathrm{mm})\end{array}$ & $\begin{array}{l}\text { Visual } \\
\text { acuity }\end{array}$ & $\begin{array}{l}\text { Primary cause } \\
\text { of blindness }\end{array}$ & $\begin{array}{l}\text { Other ocular } \\
\text { abnormalities }\end{array}$ \\
\hline \multirow[t]{2}{*}{13} & 5 & $9 \cdot 0$ & $4 / 60$ & Chorioretinal coloboma & \multirow{5}{*}{$\begin{array}{l}\text { ON coloboma, cataract } \\
\text { ON coloboma, cataract } \\
\text { Squint } \\
\text { Mild cataract } \\
\text { Iris dysplasia } \\
\text { Iris dysplasia, mild } \\
\text { cataract }\end{array}$} \\
\hline & & $8 \cdot 0$ & $3 / 60$ & Chorioretinal coloboma & \\
\hline \multirow[t]{2}{*}{14} & 8 & $8 \cdot 0$ & CF & Chorioretinal coloboma & \\
\hline & & $8 \cdot 0$ & $4 / 60$ & Chorioretinal coloboma & \\
\hline 15 & 10 & $\begin{array}{l}5 \cdot 5 \\
6 \cdot 0\end{array}$ & $\begin{array}{l}\text { PL } \\
\text { NPL }\end{array}$ & $\begin{array}{l}\text { Chorioretinal coloboma } \\
\text { Chorioretinal coloboma }\end{array}$ & \\
\hline 16 & 13 & $9 \cdot 0$ & $1 / 60$ & Chorioretinal coloboma & \multirow{3}{*}{$\begin{array}{l}\text { Cataract removed } \\
\text { Cataract removed }\end{array}$} \\
\hline \multirow{2}{*}{17} & 15 & $\begin{array}{l}9 \cdot 0 \\
9 \cdot 0\end{array}$ & $2 / 60$ & Chorioretinal coloboma & \\
\hline & (1) & $\begin{array}{l}9 \cdot 0 \\
8 \cdot 5\end{array}$ & $\begin{array}{l}4 / 60 \\
3 / 60\end{array}$ & $\begin{array}{l}\text { Chorioretınal coloboma } \\
\text { Chorioretinal coloboma }\end{array}$ & \\
\hline \multirow[t]{2}{*}{18} & 8 & $8 \cdot 0$ & $2 / 60$ & Chorioretinal coloboma & \multirow{4}{*}{$\begin{array}{l}\text { Retinal detachment } \\
-9.0 \text { sphere } \\
-9.0 \text { sphere }\end{array}$} \\
\hline & & $8 \cdot 0$ & PL & Chorioretinal coloboma & \\
\hline 19 & 10 & $8 \cdot 0$ & $5 / 60$ & Degenerative myopia & \\
\hline & & $8 \cdot 0$ & $5 / 60$ & Degenerative myopia & \\
\hline
\end{tabular}

$\mathrm{CF}=$ counting fingers $\mathrm{HM}=$ hand movements $\mathrm{NPL}=$ no perception of light $\mathrm{ON}=$ optic nerve.

Table 3 Bilateral blindness in microphthalmos with unknown aetiology

\begin{tabular}{|c|c|c|c|c|c|}
\hline $\begin{array}{l}\text { Patient } \\
\text { No }\end{array}$ & $\begin{array}{l}\text { Age } \\
\text { (years) }\end{array}$ & $\begin{array}{l}\text { Corneal } \\
\text { diameter } \\
(\mathrm{mm})\end{array}$ & $\begin{array}{l}\text { Visual } \\
\text { acuity }\end{array}$ & $\begin{array}{l}\text { Ocular } \\
\text { abnormalities }\end{array}$ & $\begin{array}{l}\text { Fundal } \\
\text { view }\end{array}$ \\
\hline 20 & 7 & $\begin{array}{l}4 \cdot 0 \\
4 \cdot 0\end{array}$ & $\begin{array}{l}\text { NPL } \\
\text { NPL }\end{array}$ & - & No \\
\hline 21 & 8 & 5.0 & NPL & 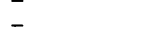 & No \\
\hline & & $5 \cdot 0$ & NPL & - & No \\
\hline 22 & 8 & 6.0 & NPL & - & No \\
\hline 23 & 10 & $\begin{array}{l}6 \cdot 0 \\
6 \cdot 0 \\
6 \cdot 0\end{array}$ & $\begin{array}{l}\text { NPL } \\
\text { NPL }\end{array}$ & Sclerocornea & $\begin{array}{l}\text { No } \\
\text { No }\end{array}$ \\
\hline 24 & 11 & $\begin{array}{l}6.0 \\
6.0\end{array}$ & $\begin{array}{l}\text { NPL } \\
\text { NPL }\end{array}$ & $\begin{array}{l}\text { Sclerocornea } \\
\text { - }\end{array}$ & No \\
\hline 25 & 11 & $\begin{array}{l}6.0 \\
3 \cdot 0 \\
3 \cdot 0\end{array}$ & $\begin{array}{l}\text { NPL } \\
\text { NPL } \\
\text { NPL }\end{array}$ & $\bar{z}$ & $\begin{array}{l}\text { No } \\
\text { No } \\
\text { No }\end{array}$ \\
\hline 26 & 13 & $\begin{array}{l}4 \cdot 0 \\
4 \cdot 0\end{array}$ & $\begin{array}{l}\text { PL } \\
\text { PL }\end{array}$ & $\begin{array}{l}\text { Sclerocornea } \\
\text { Sclerocornea }\end{array}$ & $\begin{array}{l}\text { No } \\
\text { No }\end{array}$ \\
\hline 27 & 18 & $\begin{array}{l}6.0 \\
6.0\end{array}$ & $\begin{array}{l}\text { NPL } \\
\text { NPL }\end{array}$ & $\begin{array}{l}\text { Sclerocornea } \\
\text { Sclerocornea }\end{array}$ & $\begin{array}{l}\text { No } \\
\text { No }\end{array}$ \\
\hline
\end{tabular}

$\mathrm{PL}=$ perception of light; NPL = no perception of light.

Table 4 Best corrected visual outcome compared with corneal diameter

\begin{tabular}{lll}
\hline & \multicolumn{2}{l}{ Corneal diameter } \\
\cline { 2 - 3 } Visual acuity & $\leqslant 6 \mathrm{~mm}$ & $>6 \mathrm{~mm}$ \\
\hline$>6 / 60$ to $1 / 60$ & - & 18 \\
Counting fingers & 1 & 2 \\
Hand movements & - & 2 \\
Perception of light & 4 & 5 \\
No perception of light & 21 & 1 \\
Total & 26 & 28 \\
\hline
\end{tabular}

and therefore had 'congenital' cataract. Only two patients had not had a previous lensectomy and no patient had received an intraocular lens either as a primary or a secondary procedure. Patient 2 had no perception of light bilaterally and $5.0 \mathrm{~mm}$ diameter corneas and surgery had not been offered. Patient 10 had a lensectomy in one eye which revealed PHPV. This eye eventually had NPL postoperatively and surgery was not performed in the other eye. Of the 23 lensectomies performed, the major complications were phthisis bulbi (3/23) and retinal detachment $(2 / 23)$. Glaucoma was diagnosed after ocutome lensectomy in three eyes but it could not be determined whether this was a primary abnormality or secondary to the surgery. The angles were open in all cases.

Within the group of patients with a predominantly retinal cause for their blindness, chorioretinal coloboma involving the macula affected 12/14 eyes and myopic chorioretinal degeneration affected 2/14 eyes. Other ocular abnormalities within this group were common. Cataract was present in 4/14 eyes but in each case was mild and in another two cases had been surgically removed. Mild cataract was defined as clinically insufficient to significantly impair the visual acuity.

Table 3 details the group for whom a specific cause of visual impairment could not be determined. All but $2 / 16$ eyes had NPL. In all cases, it was claimed that the child had been 'blind' from birth, rather than having a gradual deterioration in vision. No eye had undergone surgery. The mean corneal diameters were smaller than in the cataract and retinal group; $5.0 \mathrm{~mm} v 7.1 \mathrm{~mm}$ and $8.0 \mathrm{~mm}$ respectively. Six eyes had sclerocornea and an adequate fundal view was not possible in any of these 16 eyes. This was because of the small pupils which typically failed to dilate and, regardless, could not have dilated beyond 2.5-3.0 $\mathrm{mm}$ because of the size of the anterior segment. B scan ultrasound was performed on $10 / 16$ of these eyes and this revealed no abnormality in the anterior or posterior segments in any eye except for the decreased size of the globe. Electrophysiological investigations were not performed. The summary of best corrected visual acuity, compared with horizontal corneal diameter, is presented in Table 4 . Those patients with corneal diameters greater than $6 \mathrm{~mm}$ were more likely to achieve an acuity of better than perception of light compared with those with smaller corneas $(p<0.001)$.

\section{Discussion}

Previous classifications of microphthalmos have been based on anatomical abnormalities. ${ }^{1-3}$ However, it is useful for the clinician also to be able to estimate the ultimate visual outcome, especially when microphthalmos is often apparent early in life. ${ }^{1-3}$ Weiss $e t$ al ${ }^{1}$ have previously shown that simple microphthalmos is associated with a good visual outcome with $21 / 22$ patients achieving better than $6 / 18$ even though $82 \%$ had at least $+7 \cdot 0$ dioptres of hypertropia. In contrast, this study looks at patients that ultimately became severely visually impaired or blind because of microphthalmos. In keeping with Weiss et al's 
series, ${ }^{1}$ there were no patients with simple microphthalmos within this study group.

The commonest cause of blindness was congenital cataract ${ }^{510-12}(44 \%, 24 / 54)$ and mild cataract was also present in another six eyes. Lensectomy had been performed on 23 eyes and this had been followed by phthisis bulbi in three eyes and retinal detachment in two eyes. Therefore, $22 \%(5 / 23)$ of patients had a major complication leading to, at best, perception of light. The combination of microphthalmos and aphakia produces very high hypermetropia but for economic reasons (the per capital gross national product of the region is $£ 1000-£ 1300^{17}$ ), no child had a trial of contact lenses for the aphakia.

Chorioretinal coloboma involving the macula was the second commonest cause of blindness affecting $22 \%$ of eyes (12/54). It was also present to a mild degree in another two eyes. This group of patients was also associated with cataract and iris dysplasia (7/12). Glaucoma overall was uncommon, affecting only three eyes, all of whom had previous cataract surgery. However, it was uncertain whether this was related to the surgery. No patient had angle closure as has been previously noted in association with this condition. ${ }^{18}$

PHPV was found in only one eye in this series. This is in accordance with the observation that PHPV is associated with microphthalmos almost always in unilateral disease. ${ }^{1}$ High myopia with degenerative chorioretinal degeneration affected both eyes of one patient and this may occur as a specific, inheritable entity. ${ }^{19}$

The patients classified into the unknown aetiology group remain a problem. In general, these patients had the smallest eyes (mean corneal diameter $=5.0 \mathrm{~mm}$ ) and a fundal view was precluded because of sclerocornea $(6 / 16)$, or a small pupil and the presence of nystagmus. Sclerocornea is known to be associated with microphthalmos. ${ }^{20}$ However, the visual acuity was NPL in 14 and PL in the other two eyes. Ultrasound examination showed small globes but normal vitreous and anterior segments. This, together with the history of being 'blind from birth', suggests that there was a severe primary developmental defect in the retina or optic nerve. This is in keeping with Weiss et al's findings ${ }^{2}$ that in complex microphthalmos, $80 \%$ had a malformation of the posterior segment. A clinicopathological case report of a stillborn child with Meckel-Gruber syndrome and microphthalmos with corneal diameters of 4.0 and $6.0 \mathrm{~mm}$ showed severe retinal dysplasia and optic nerve dysplasia. ${ }^{21}$

The comparison of corneal diameter with visual acuity shows the marked tendency for eyes that have corneas less than or equal to $6 \mathrm{~mm}$ to have a poor acuity. However, the corneal diameter was measured in patients from age 5 to 20 years and it is difficult to extrapolate this to findings in early infancy. In microphthalmos, the natural history of the growth of the cornea from birth to adulthood is unknown but it is possible that it follows a similar pattern to normal eyes. A normal cornea has a horizontal diameter of 10.0 $\mathrm{mm}$ at birth and has reached adult dimensions of $11.8 \mathrm{~mm}$ by 2 years of age. ${ }^{22}{ }^{23}$ By analogy, a $6 \mathrm{~mm}$ cornea in adulthood is equivalent to a $5.1 \mathrm{~mm}$ diameter cornea at birth $(6.0 \times 10 \cdot 0 / 11 \cdot 8=5 \cdot 1$ $\mathrm{mm}){ }^{1819}$ Therefore, a newborn child with microphthalmos and a corneal diameter of $5 \mathrm{~mm}$ or less has a very poor visual prognosis.

The author acknowledges the help and assistance of Mr Romain De Cock, FRCS and the Order of St John.

1 Weiss AH, Kousseff BG, Ross EA, Longbottom J. Simple microphthalmos. Arch Ophthalmol 1989; 107: 1625-30.

2 Weiss AH, Kousseff BG, Ross EA, Longbottom J. Complex microphthalmos. Arch Ophthalmol 1989; 107: 1619-24.

3 Duke-Elder S. System of ophthalmology. Vol III. London: Kimpton, 1964: 488-95.

4 Bateman JB. Microphthalmos. Int Ophthalmol Clin 1984; 24: 87-107.

5 Capella JA, Kaufman HE, Lill FJ, Cooper G. Hereditary cataracts and microphthalmia. Am $\mathcal{F}$ Ophthalmol 1963; 56: 454-8.

6 Francois J. A new syndrome: dyscephalia with a bird face and dental abnormalities, nanism, hypotrichosis cutaneous atrophy, microphthalmia and congenital cataract. Arch Ophthalmol 1958; 60: 842-62.

7 Haddad R, Font RL, Resser F. Persistent hyperplastic primary vitreous: a clinicopathological study of 62 cases and review of the literature. Surv Ophthalmol 1978; 23: 123-43.

8 Mann I. Developmental abnormalities of the eye. London Cambridge University Press, 1937: 65-103.

9 Shields MB, Buckley E, Klintworth GK, Thresher R. Axenfeld-Rieger syndrome: a spectrum of developmental disorders. Surv Ophthalmol 1985; 29: 387-409.

10 Waardenburg PJ, Franceschetti A, Klein D. Genetics and ophthalmology. Springfield, IL: Thomas, 1961: 880-1.

11 Witkop-Oostenrijk GA. Microphthalmia, microcornea and congenital cataract. Ned Tijdschr Geneeskd 1956; 100 2910-3.

12 Zeiter HJ. Congenital microphthalmos. Am $\mathcal{F}$ Ophthalmol 1963; 55: 910-21.

13 Warburg $M$. An update on microphthalmos and coloboma. Ophthalmol Paediatr Genet 1991; 12: 57-63.

14 Falls HF, Schull WJ. Hallerman-Streiff syndrome. Arch Ophthalmol 1960; 63: 409-20.

15 Warburg M. Genetics of microphthalmos. Int Ophthalmol $1981 ; 4: 45-65$

16 Elder MJ, De Cock R. Childhood blindness in the West Bank and Gaza Strip; aetiology, prevalence and the influence of hereditary factors. Eye 1993; 4: 580-3

17 Health in Judea, Samaria and Gaza 1991. State of Israel, Ministry of Health, 1991.

18 Kimbrough RL, Trempe CS, Brocklehurst RJ, Simmons RJ. Angle-closure in nanophthalmos. Am 7 Ophthalmol 1979; Angle-closur

19 Usher CH. A pedigree of microphthalmia with myopia and corectopia. Br f Ophthalmol 1921; 5: 289-99.

20 Goldstein JE, Cogan DG. Sclerocornea and associated congenital abnormalities. Arch Ophthalmol 1962; 67: 99-106.

21 Jones KL. Smiths's recognizable patterns of human malformation. Philadelphia: Saunders, 1988: 152-3.

22 Hymes C. The postnatal growth of the cornea and palpebral fissure and the projection of the eyeball in early life. $\mathcal{F}$ Comp Neurol 1929; 48: 415.

23 Duke-Elder S. System of ophthalmology. Vol II. London: Kimpton, 1961: 93-4. 